\title{
Pipe bridge design optimisation through a comparative study of truss and girder arrangements
}

Optimización del diseño de puente de tubería mediante un estudio comparativo de cercha y

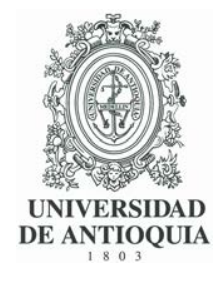
viga

\author{
S. V. Sivapriya (iD ${ }^{1 *}$, S. Sadhana (iD ${ }^{2}$, N. Prathibha (iD ${ }^{2}$, S. Saranya (iD) ${ }^{2}$ \\ ${ }^{1}$ Associate Professor, Department of Civil Engineering, Sri Sivasubramaniya Nadar College of Engineering. Kalavakkam, \\ Chennai. P. C. 603110 Tamil Nadu, India. \\ ${ }^{2}$ Former Undergraduate Students, Department of Civil Engineering, Sri Sivasubramaniya Nadar College of Engineering. \\ Kalavakkam, Chennai. C. P. Tamil Nadu, India.
}

\section{CITE THIS ARTICLE AS:}

\author{
S. V. Sivapriya, S. Sadhana, N. \\ Prathibha and S. Saranya. \\ "Pipe bridge design \\ optimisation through a \\ comparative study of truss and \\ girder arrangements", Revista \\ Facultad de Ingeniería \\ Universidad de Antioquia, no. \\ 106, pp. 56-65, Jan-Mar 2023. \\ [Online]. Available: https: \\ //www.doi.org/10.17533/ \\ udea.redin. 20210957
}

\section{ARTICLE INFO:}

Received: August 04, 2020 Accepted: September 13, 2021

Available online: September

13,2021

\section{KEYWORDS:}

Pipe bridge; girder; truss; design; analysis

Puente de tubería; viga; armadura; diseño; análisis

\begin{abstract}
Pipe bridges are structures that play an indispensable role in chemical and oil plants. They support cable trays or pipe-carrying material. This study aims to identify the ideal configuration of a pipe bridge through the comparative study of girders with drop hanger and truss arrangements for three different spans. The most efficient arrangement for each span was suitably identified. Through the analysis carried out, it was then identified that the Girder arrangement is suitable for smaller spans such as 15 meters; while the truss arrangement was preferable for longer spans.
\end{abstract}

RESUMEN: Los puentes de tuberías son estructuras que juegan un papel indispensable en las plantas químicas y petroleras. Estas soportan haces de cables o material de transporte de tuberías. Este estudio tiene como objetivo identificar la configuración ideal de un puente de tubería a través del estudio comparativo de arreglos de cerca y viga para tres tramos diferentes. La disposición más eficiente para cada tramo se identificó adecuadamente. A través del análisis realizado, se identificó que la disposición de la viga es adecuada para tramos más pequeños hasta 15 metros; mientras que la disposición de la cercha fue la más favorable para tramos más largos.

\section{Introduction}

Pipe bridges are vital structures in industrial plants for chemical, oil, gas and road or railway crossings to support pipes and cable trays. Pipe racks extending over process structures, road or railway crossings are commonly referred to as pipe bridges.

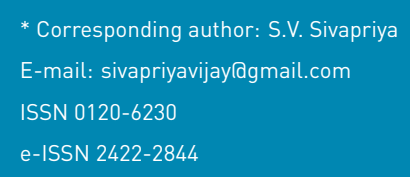

Often, pipe racks also support mechanical equipment, valve access platforms, and vessels in process units. Pipe bridges transfer material between equipment and storage areas. The most predominately used arrangements in the current day industrial practice are girder and truss arrangements.

Commonly the process lines are to be kept at a lower tier and utility and hot process lines are to be kept on the upper tier. The top tier is to be kept for electrical cable trays and instrument cable ducts to avoid short circuits, likely to be caused due to pipe leakage. To allow maintenance access 
under pipe bridges, transverse frames are used. They are typically moment-resisting frames that support gravity loads and resist lateral loads transverse to the pipe rack. The consideration needs to be given to the arrangement of pipe racks because excess pipe length would add up to the expense, and optimization in design would help in saving capital on structural steel and civil costs.

The design of steel rack pipe have been studied and proposed building code, industry practice design criteria, design loads, and other design considerations for pipe racks [1]. For Saudi Aramco projects, a separate guidelines for steel pipe rack design is proposed for engineers working $i$ to its requirement [2]. The general design philosophy and requirements to be used in the analysis,design of pipe racks and also the optimal design used in oil and gas industries as per international standards is proposed due to the huge demand in the industry [3]. They also emphasize the use of plan bracings in the top and bottom tiers to control lateral deflection and the introduction of vertical bracings in both transverse and longitudinal direction to transfer the lateral forces to the base. The industrial guidelines for practising engineers and steel fabricators to design steel pipe racks, has been presented and all the critical aspects for the design of pipe racks is well analysed and published [4].

The optimal dimensioning for combined footing for large load footings to meet the contact surface on the soil, the bending moment about $X$ and $Z$ axes in each column developed due to axial load is taken care along with maximum and minimum stress [5]. The EMETL provides the standards for allowable spans, clearance, live load conditions based on the diameter of the pipe and the standard pipe-bridge load-application criteria [6].

Previous studies majorly involve understanding the behaviour of pipe rack; hence this study aims to identify the ideal configuration for pipe bridges by comparing truss and girder arrangements over three-span lengths. The key objectives of this study are:

- To design and analyse the structural efficiency for two different configurations, namely, girder and truss for a pipe-bridge over three different spans: $15 \mathrm{~m}, 20 \mathrm{~m}$, and $30 \mathrm{~m}$. The structural efficiency is dependent on the steel member take- off and deflection.

- To study the load distribution of these configurations and design their respective foundations.

- To analyse the load transfer efficiency of these configurations based on the volume of concrete obtained through the design.

- To analyse the load transfer efficiency of these configurations based on the volume of concrete obtained through the design.

- To arrive at a thumb rule to identify the ideal configuration for a given span based on cost-effective and stability aspects.

\section{Methodology}

The pipe bridge structure was modelled on STAAD Pro and the member properties were assigned to the structural steel members. Fixed supports were assigned to all the nodes that were to be joined to the foundation pedestals to prevent any further movement and rotation. The $20 \mathrm{~m}$ and $30 \mathrm{~m}$ span pipe bridges were modelled similarly; the inter stub span for the $20 \mathrm{~m}$ spans was designed to be $4 \mathrm{~m}$. The cross-section and the line sketches of the $15 \mathrm{~m}$ span pipe bridges modelled have been illustrated below (Figures 1 to 3 ).

The live loads were calculated and applied at nodes. The Wind Load intensity was calculated according to the horizontal and vertical dimensions from its corresponding nodal, and uniformly distributed wind loads were also calculated; the anchor load was identified based on piping requirements. Table 1 gives a summary of the load definitions and calculations [7].

The live load on the top and bottom tiers were assigned as uniformly distributed load and the self-weight load was assigned to all the members. The Wind load was assigned as nodal loads in the positive and negative $X$ directions and as wind intensity in the $Z$ directions. The Anchor load was assigned in the braced bay frame as per piping specifications. The wind load, anchor load, live load and dead load have been assigned as calculated in both configurations of all 3 spans (Table 1). Figure 4 to Figure 7 depict a few of the loads assigned in each span.

The design parameters such as the deflection, slenderness limits and shear releases were assigned. The girder and truss arrangements were analysed using STAAD Pro and the results were studied [9]. The members' utility/ unity ratios for each member, displayed in the post-processing mode was optimized to optimal ratios based on the governing factors such as deflection, bending, and slenderness. The overall costs for fabrication, transport, and erection were also calculated.

The design of the foundation was done using MAT3D software[10]. The checks for bearing pressure and stability were carried out using the software for a cohesionless soil with a unit weight of $18 \mathrm{kN} / \mathrm{m}^{3}$ with a minimum bearing pressure of $150 \mathrm{kN} / \mathrm{m}^{2}$ with the linear application as input parameters. Figure 8 shows the model generated and obtained analysis report. The foundations' settlement behaviour and base pressure variations were 


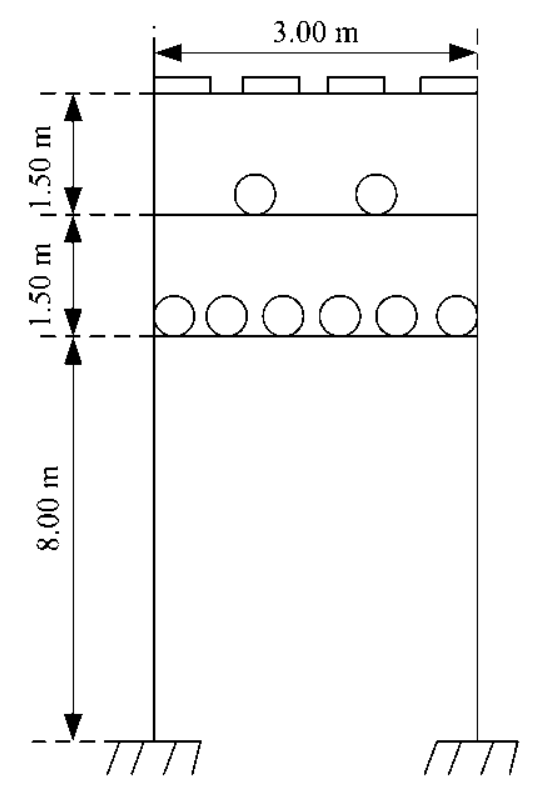

Tier 1 - Cable Trays

Tier 2 - 16" diameter pipe

Tier 3 - 12" diameter pipe

Figure 1 Line sketch of $15 \mathrm{~m}$ girder configuration

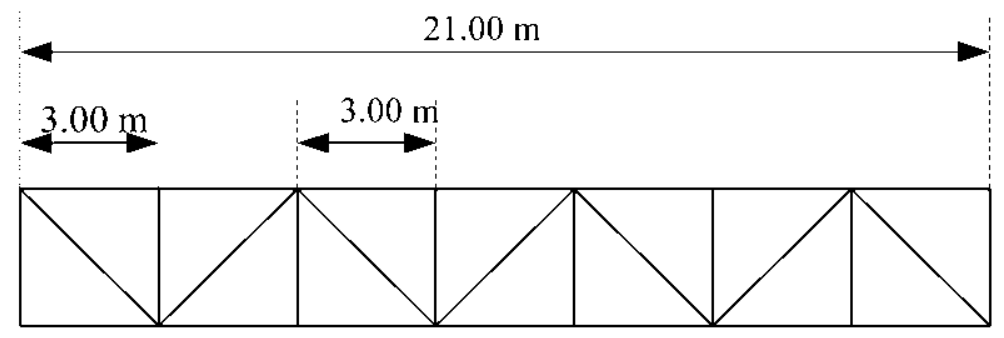

\section{Drawn Not to} scale

Figure 2 Top view of truss of $15 \mathrm{~m}$ truss configuration

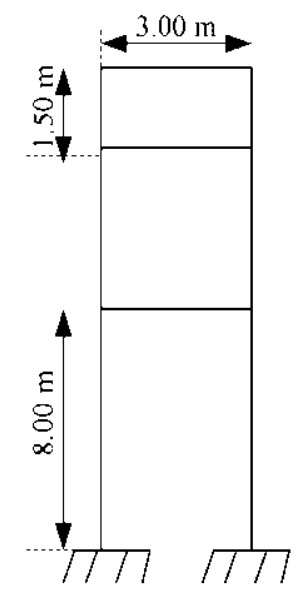

i. I.eft Side view

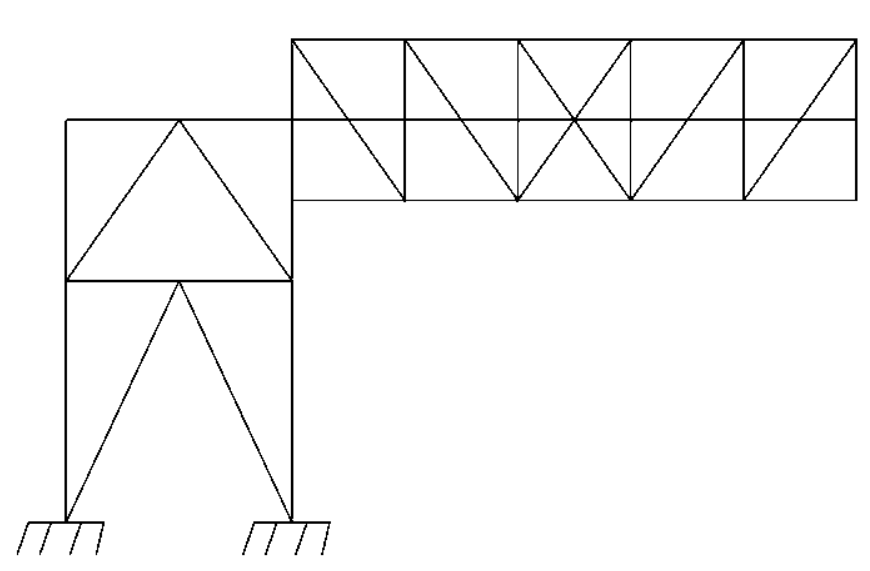

ii. Front view

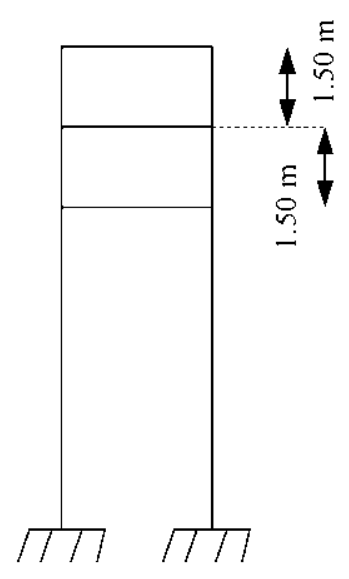

iii . Right side view

Drawn Not to scale

Figure 3 Left, right side and front view of $15 \mathrm{~m}$ truss configuration 
Table 1 Load definition summary

\begin{tabular}{cc}
\hline $\begin{array}{c}\text { Dead Load (DL) } \\
\text { Self-Weight of Structure }\end{array}$ & $\begin{array}{c}\mathbf{0 . 5} \mathrm{kN} / \mathrm{m}^{2} \text { (UDL) } \\
\text { As considered in STAAD Pro }\end{array}$ \\
$\begin{array}{cc}\text { Live Load (LL) } \\
\begin{array}{c}\text { For pipe bridges supporting cable trays or } \\
\text { pipes of diameter less than 12 inches }\end{array}\end{array}$ & $\begin{array}{c}\text { In transverse beam for every } 3 \mathrm{~m} \text { span } 18 \mathrm{kN} \\
\text { vertical load 6kN lateral load }\end{array}$ \\
$\begin{array}{c}\text { The loads given by piping discipline for } \\
\text { 16- inch diameter pipes in tier 2 is } \\
\text { inclusive of both live and dead loads las } \\
\text { per piping stress input) }\end{array}$ & $\begin{array}{c}\text { In a transverse beam of the end span (final } \\
\text { transverse beam) 22kN vertical load 10kN } \\
\text { lateral load }\end{array}$ \\
\hline Anchor Load (AL) & Calculated as per (IS 875 Part III) [8] \\
\hline Friction Load (FL) & $\begin{array}{c}\text { 10 kN Applied in braced bay according to the } \\
\text { location furnished by piping discipline. }\end{array}$ \\
\hline Seismic Load (SL) & $\begin{array}{c}\text { Friction forces generated in pipes are } \\
\text { counterbalanced by adjacent pipes and load } \\
\text { generated due to friction is hence nullified. }\end{array}$ \\
\hline
\end{tabular}

analysed.

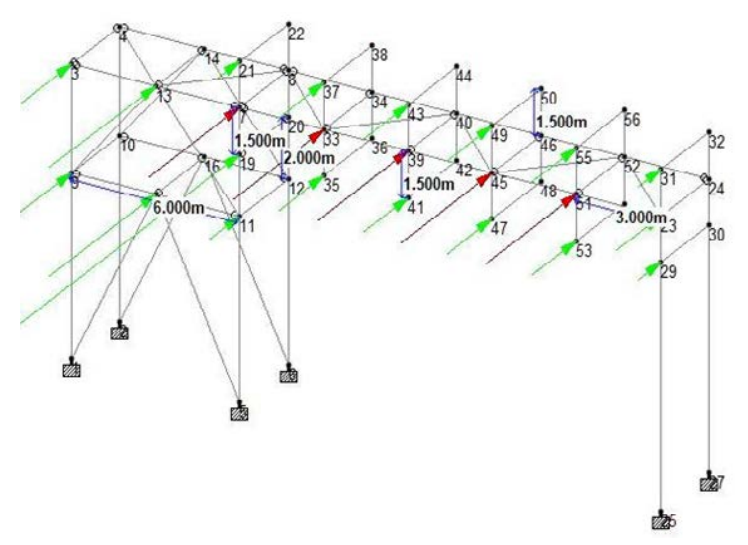

Figure 4 Wind load application on 15 m girder configuration in $+\mathrm{X}$ direction

\section{Results and discussion}

The steel member take-off, cost, and member profiles of girder and truss arrangements for the three spans have been compared as illustrated in Table 2-4.

The following chart (Figure 9, 10) illustrates that the trend of the steel member take-off for the two arrangements varies in proportion to the span length.

It could be used to finalize the pipe bridge arrangement to be used for a specific span. Further, the steel quantities

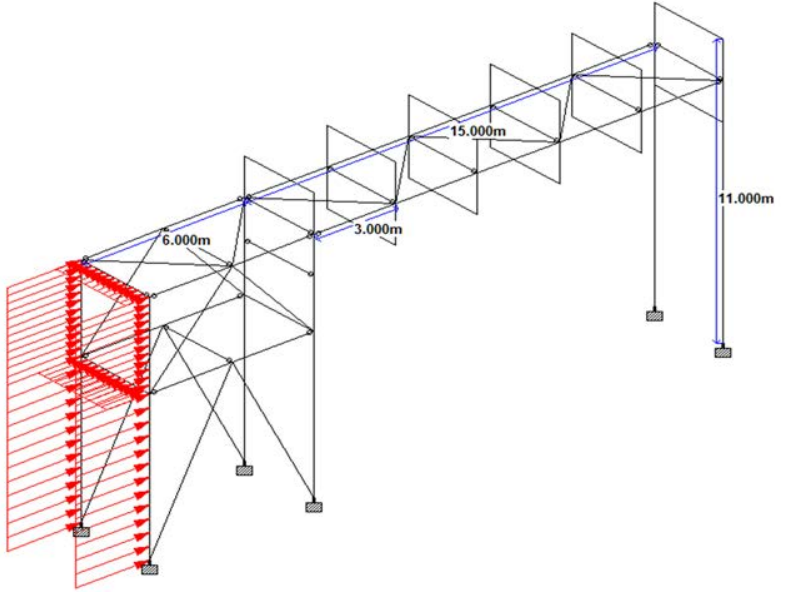

Figure $\mathbf{5}$ Wind Load application in $15 \mathrm{~m}$ girder configuration in $+Z$ direction

required and the corresponding costs of pipe bridge construction can be, therefore, predicted using the quadratic equation from the resultant data. The base pressures developed in the foundation are depicted in the form of contours (Figure 11-16).

The longitudinal beams and vertical bracings in the truss arrangement tend to transfer a higher load to the columns than that of the girder arrangement. This results in a difference in the direction and magnitude of moments acting on the pedestal, thereby affecting the base pressure distribution.

The following are the observations from the study; 


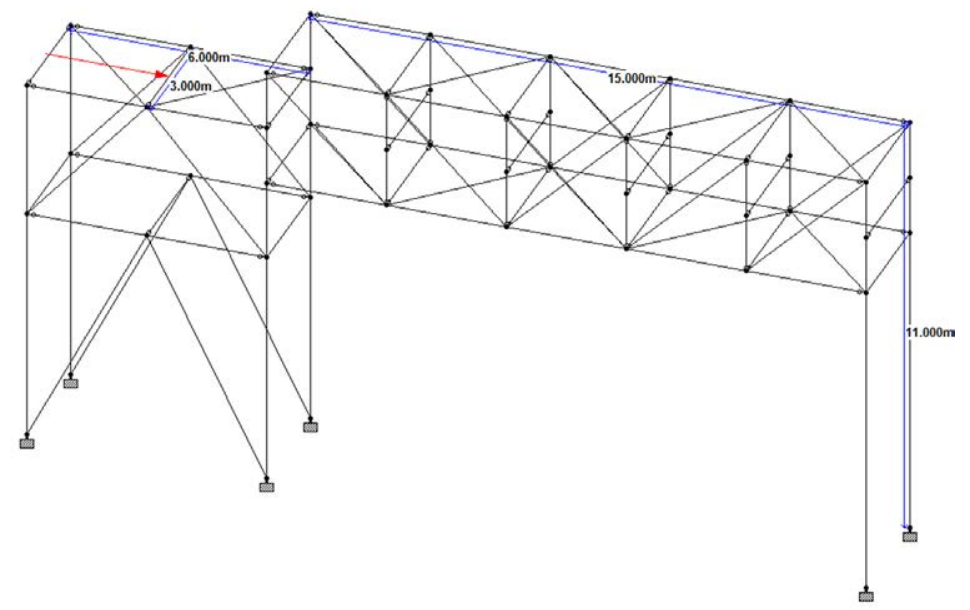

Figure 6 Anchor Load Application on $15 \mathrm{~m}$ Truss configuration

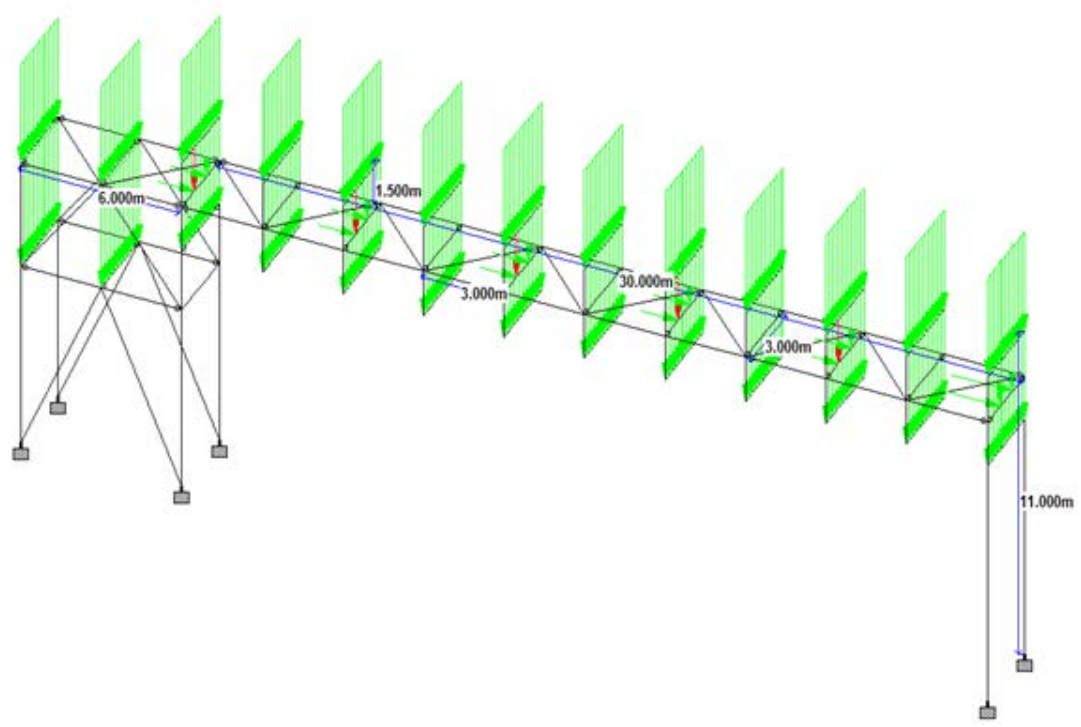

Figure 7 Live Load Application on 30m beam configuration in Tier 2

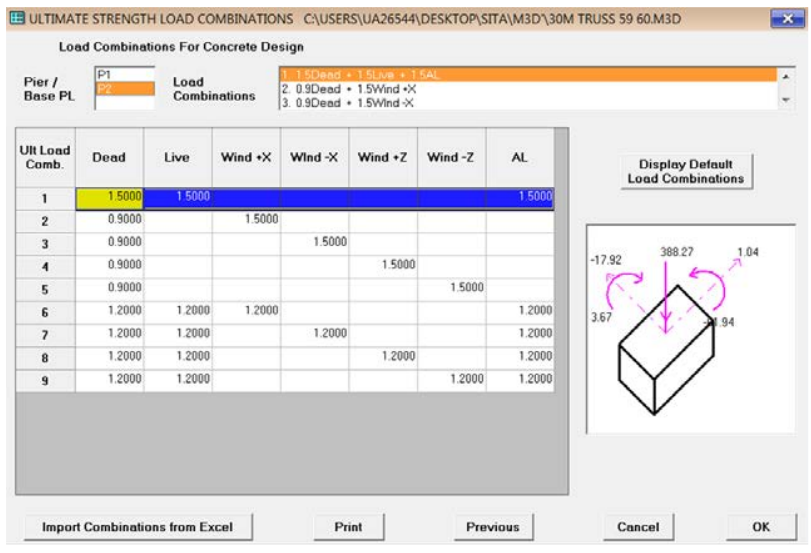

(a)

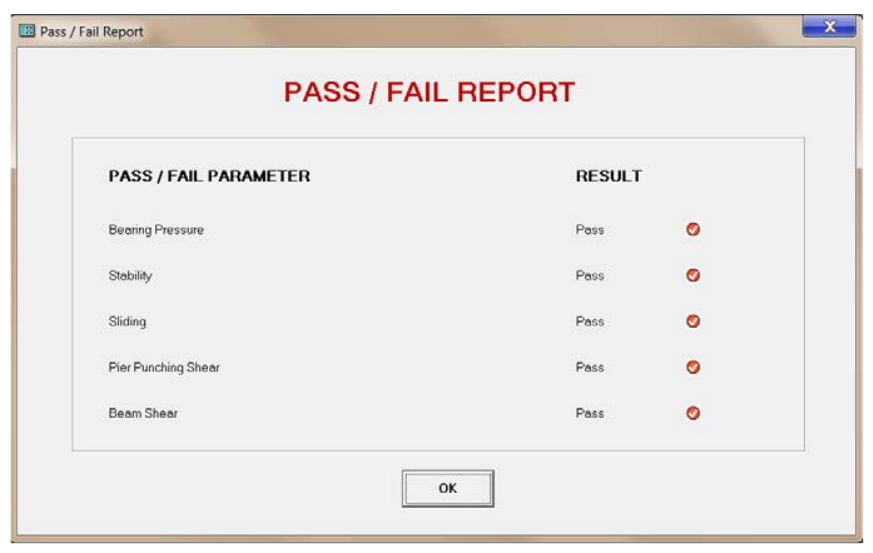

(b)

Figure 8 Input and output in MAT3D 
Table 2 Comparison between $15 \mathrm{~m}$ girder and truss arrangement

\begin{tabular}{|c|c|c|c|c|c|}
\hline & \multicolumn{2}{|c|}{ 15m Girder } & \multicolumn{2}{|l|}{ 15m Truss } & \\
\hline Take-off, MT & 12.94 MT & & 13.15 & & \\
\hline Cost, USD & 17052.46 & & 17310.63 & & \\
\hline \multirow{9}{*}{ Member profile } & \multirow{6}{*}{ Beam } & $\begin{array}{c}\text { Longitudinal } \\
\text { ISMB } 600\end{array}$ & \multirow{9}{*}{ Member Profile } & \multirow{6}{*}{ Beam } & $\begin{array}{c}\text { Longitudinal } \\
\text { ISMB } 250\end{array}$ \\
\hline & & Lateral & & & Lateral \\
\hline & & ISMB 200 & & & ISMB 250 \\
\hline & & ISMB 400 & & & ISMB 200 \\
\hline & & ISMB 300 & & & ISMB 300 \\
\hline & & ISMB 350 & & & ISMB 450 \\
\hline & Column & ISWB 600H & & Column & ISWB 600H \\
\hline & Stub & ISMB 200 & & Strut & ISMB 200 \\
\hline & Bracing & ISHT 100 & & Bracing & ISHT 100 \\
\hline
\end{tabular}

Table 3 Comparison between 20m Girder and Truss arrangement

\begin{tabular}{|c|c|c|c|c|c|}
\hline \multirow{3}{*}{$\begin{array}{l}20 \text { m Girder } \\
\text { Take-off, MT } \\
\text { Cost, USD }\end{array}$} & \multicolumn{5}{|c|}{$20 \mathrm{~m}$ Truss } \\
\hline & \multicolumn{2}{|l|}{20.1} & Take-off, MT & \multicolumn{2}{|l|}{15.4} \\
\hline & \multicolumn{2}{|l|}{26468.9} & Cost, USD & 20231.97 & \\
\hline \multirow{3}{*}{ Member profile } & \multirow[t]{2}{*}{ Beam } & $\begin{array}{l}\text { Longitudinal } \\
\text { Plate girder is } \\
\text { Overall depth } \\
0.65 \mathrm{~m} \text { Web } \\
\text { thickness } 0.02 \mathrm{~m} \\
\text { Flange width } 0.3 \mathrm{~m} \\
\text { Flange thickness } \\
0.03 \mathrm{~m}\end{array}$ & \multirow{2}{*}{ Member profile } & \multirow[t]{2}{*}{ Beam } & $\begin{array}{l}\text { Longitudinal } \\
\text { ISMB } 250 \\
\text { ISMB } 225\end{array}$ \\
\hline & & $\begin{array}{l}\text { Lateral } \\
\text { ISMB } 200 \\
\text { ISMB } 400 \\
\text { ISMB } 450\end{array}$ & & & $\begin{array}{l}\text { Lateral } \\
\text { ISMB } 250 \\
\text { ISMB } 200 \\
\text { ISMB } 450 \\
\text { ISMB } 500\end{array}$ \\
\hline & $\begin{array}{l}\text { Column } \\
\text { Stub } \\
\text { Bracing }\end{array}$ & $\begin{array}{l}\text { ISWB 600H } \\
\text { ISMB } 200 \\
\text { ISHT } 125\end{array}$ & & $\begin{array}{l}\text { Column } \\
\text { Strut } \\
\text { Bracing }\end{array}$ & $\begin{array}{l}\text { ISWB 600H } \\
\text { ISMB } 250 \\
\text { ISHT } 125\end{array}$ \\
\hline
\end{tabular}

- Though the difference in the quantity of steel between girder and truss configuration for $15 \mathrm{~m}$ span was 0.16 tonnes, the girder with hanger configuration was still considered to be preferable because of the use of rolled sections.

- For $20 \mathrm{~m}$ span, a quantity of steel for girder and truss configuration was found to be 20.1 MT and 15.4 MT, respectively and the overall cost for construction of pipe bridge for $20 \mathrm{~m}$ span was found to be 26468.69 USD for girder arrangement and 20231.97 USD for truss configuration. Hence, the truss configuration was found to be the most appropriate fora span length longer than $15 \mathrm{~m}$.

- The girder arrangement would require the usage of built-up sections, which would increase the fabrication cost due to welding. Also, there are high chances for the beam to deflect while lifting during the erection of the pipe bridge.

- The difference in steel tonnage for $30 \mathrm{~m}$ span was found to be over $10 \mathrm{MT}$, and the difference in construction cost was nearly 13587.62 USD. Considering these aspects, the truss arrangement was found to be the most suitable.

- Also, the depth of plate girders used in girder configuration was invariably high (1.2 $\mathrm{m}$ in our case) and involved the use of web stiffeners to prevent web crippling and buckling. This led to an increase in steel tonnage and overall cost because of the additional cost of fabrication involved.

- With the increase in width of the span, the stress overlaps with each other, which leads to more 
Table 4 Comparison between $30 \mathrm{~m}$ girder and truss arrangement

\begin{tabular}{|c|c|c|c|c|c|}
\hline \multicolumn{3}{|l|}{30 m Girder } & \multicolumn{3}{|l|}{$30 \mathrm{~m}$ Truss } \\
\hline \multirow{2}{*}{$\begin{array}{l}\text { Take-off, MT } \\
\text { Cost, USD }\end{array}$} & \multicolumn{2}{|l|}{39.9} & \multirow{2}{*}{$\begin{array}{l}\text { Take-off, MT } \\
\text { Cost, USD }\end{array}$} & \multicolumn{2}{|l|}{29.0995} \\
\hline & \multicolumn{2}{|l|}{52584.09} & & \multicolumn{2}{|l|}{38344.27} \\
\hline \multirow{12}{*}{ Member profile } & \multirow[t]{5}{*}{ Beam } & $\begin{array}{l}\text { Longitudinal } \\
\text { Plate girder } \\
\text { Overall depth } 1.2 \mathrm{~m} \\
\text { Web thickness } 0.025 \mathrm{~m} \\
\text { Flange width } 0.35 \mathrm{~m} \\
\text { Flange thickness } 0.03 \mathrm{~m}\end{array}$ & \multirow{12}{*}{ Member profile } & \multirow[t]{5}{*}{ Beam } & $\begin{array}{l}\text { Longitudinal } \\
\text { ISMB } 250 \\
\text { ISMB } 300\end{array}$ \\
\hline & & Lateral & & & Lateral \\
\hline & & ISMB 200 & & & ISMB 200 \\
\hline & & ISMB 400 & & & ISMB 300 \\
\hline & & ISMB 350 & & & ISMB 400 \\
\hline & \multirow{5}{*}{ Column } & Plate girder & & \multirow{5}{*}{ Column } & Plate girder \\
\hline & & Overall depth $0.65 \mathrm{~m}$ & & & Overall depth $0.9 \mathrm{~m}$ \\
\hline & & Web thickness $0.02 \mathrm{~m}$ & & & Web thickness $0.03 \mathrm{~m}$ \\
\hline & & Flange width $0.28 \mathrm{~m}$ & & & Flange width $0.35 \mathrm{~m}$ \\
\hline & & Flange thickness $0.023 \mathrm{~m}$ & & & Flange thickness $0.03 \mathrm{~m}$ \\
\hline & Stub & ISMB 200 & & Strut & ISMB 200 \\
\hline & Bracing & ISHT 125 & & Bracing & ISHT 100 \\
\hline
\end{tabular}

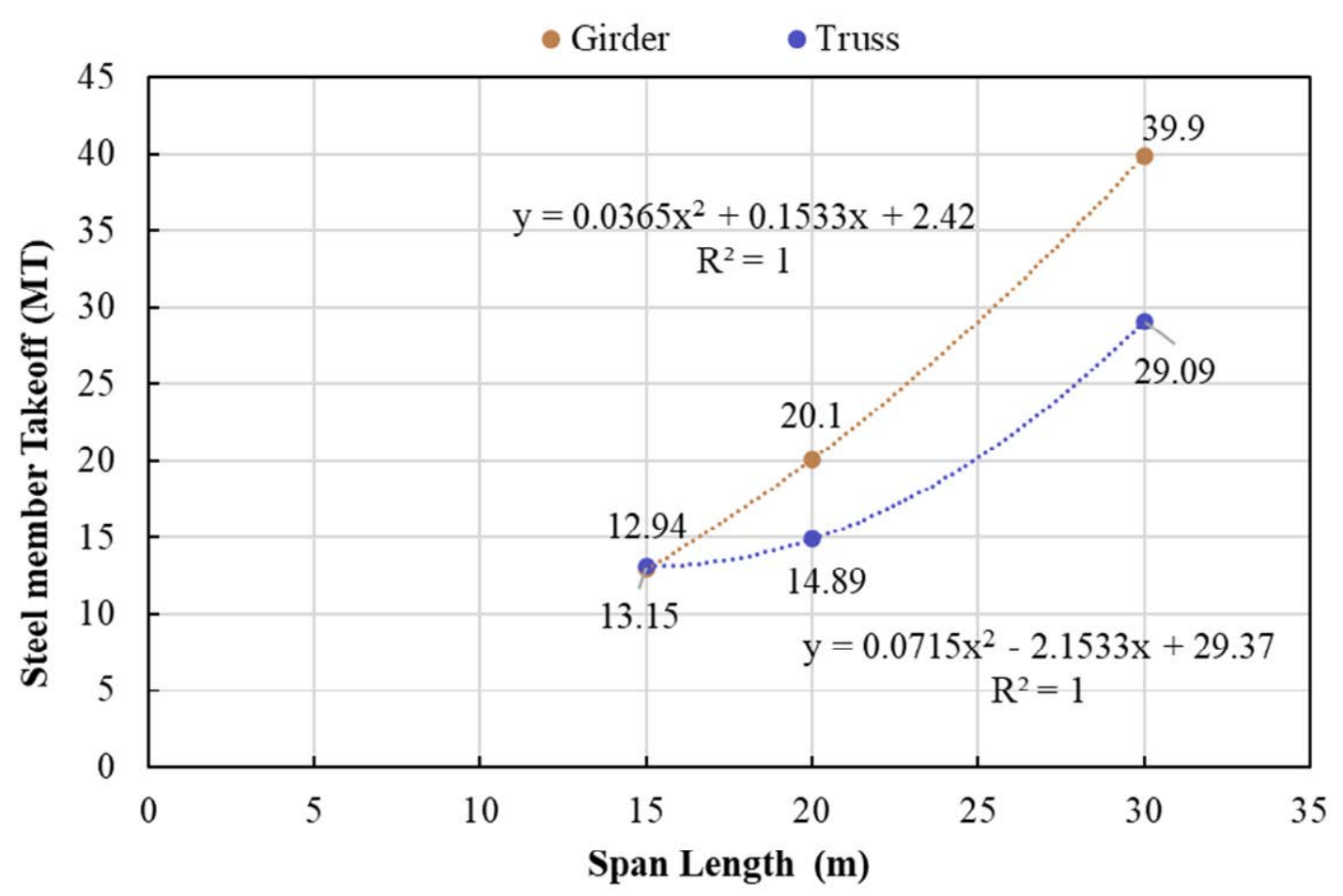

Figure 9 Trend line chart illustrating the variation of steel member take-off with span

settlement.

$15 \mathrm{~m}$ length.

- The settlement behaviour also indicates that the truss configuration can be preferred for spans greater than 


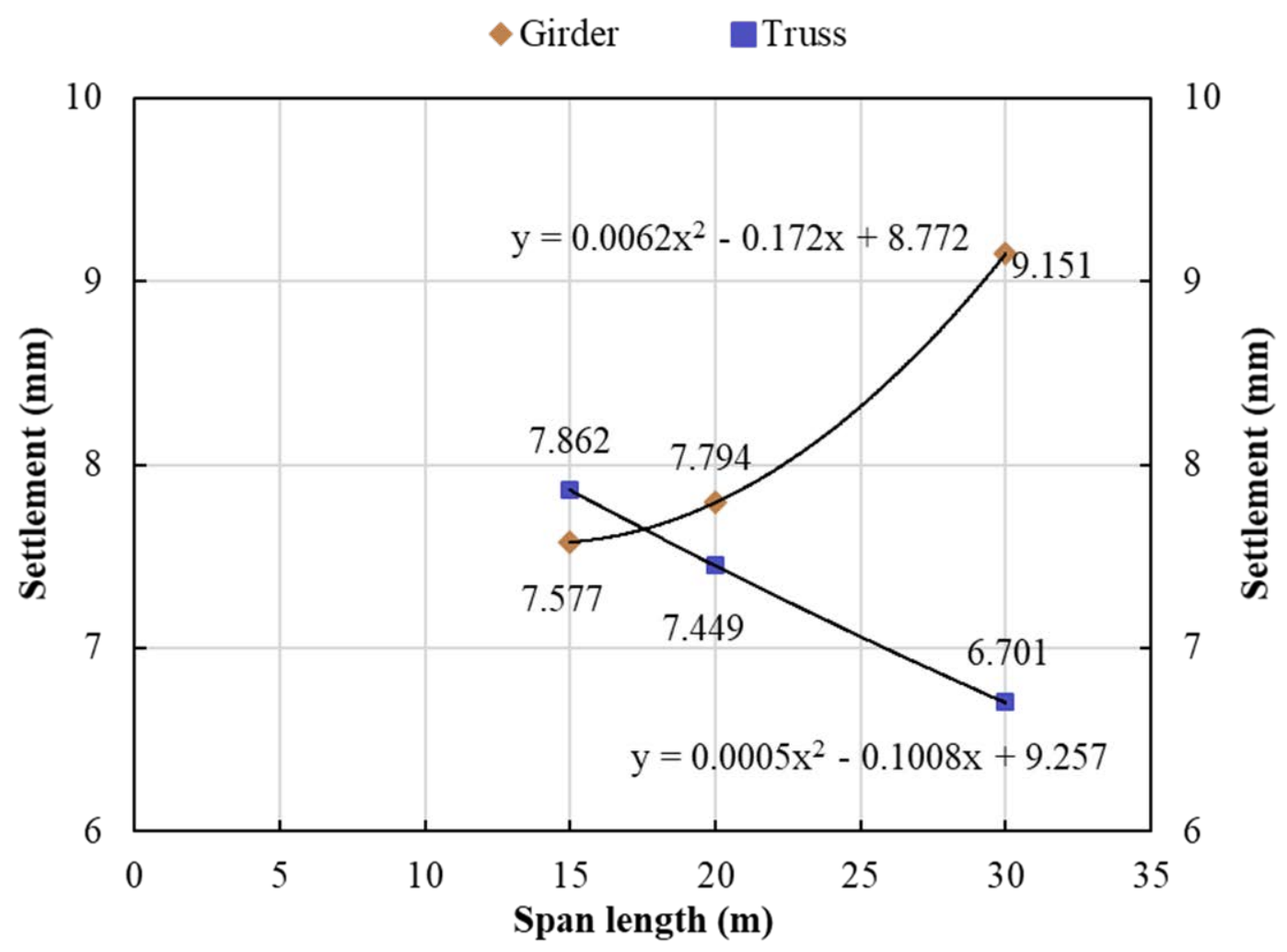

Figure 10 Settlement behaviour chart

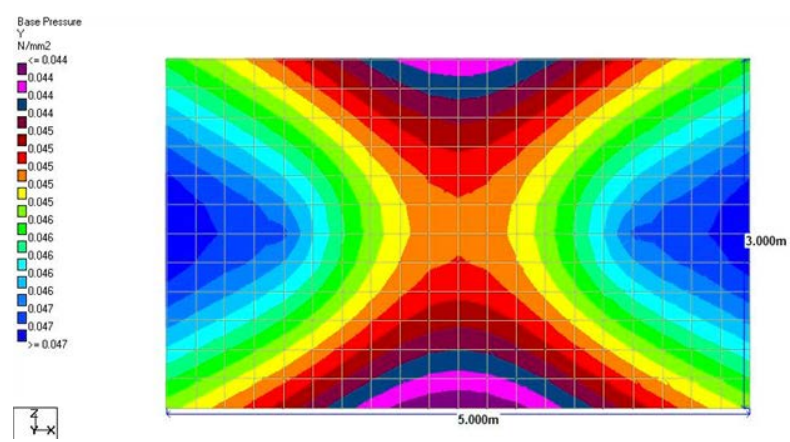

Figure 11 Base pressure distribution in 15m girder arrangement $(D L+L L+A L)$

\section{Conclusions}

Increased new-car demands also increases the need for fossil fuels. The cost of transportation from the primary source to the required location increments with an increase in distance, which varies depending upon the material/ arrangement. A detailed analysis was developed to identify the optimum span length for girder and truss arrangements. The structure was modelled using STAD Pro. and analysed through MAT 3D; the parameter analysed are steel member take-offs and deflections.

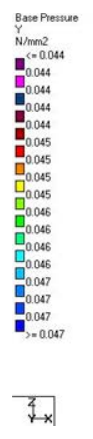

- The take-off of steel member for truss and girder at $15 \mathrm{~m}$ length span is $13.15 \mathrm{MT}$ and $12.94 \mathrm{MT}$. This increments with an increase in span length for 20 and $30 \mathrm{~m}$ length span by 2.25 and 15.1 times for the truss; for the girder, it increases by 7.16 and 25 times for 20 and $30 \mathrm{~m}$ span length, respectively.

- By considering the quantity of steel calculated, it is inferred that opting for the truss over the girder would further lead to an increase in cost owing to manpower, and also splices and connections that would be involved during fabrication with a difference 


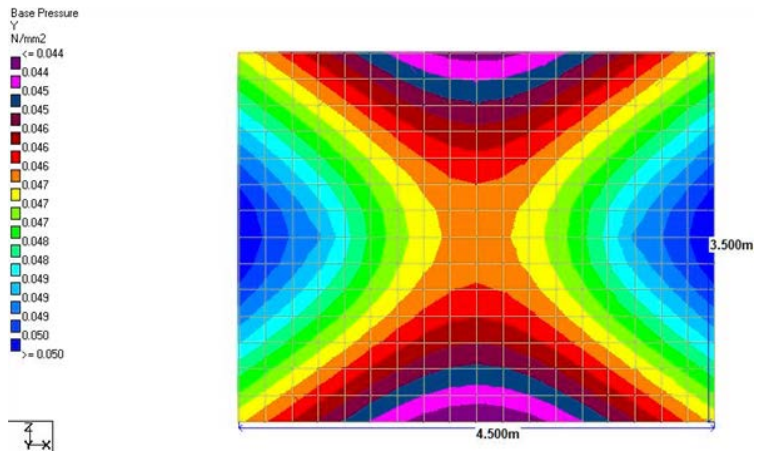

Figure 13 Base pressure distribution in $20 \mathrm{~m}$ girder arrangement $(D L+L L+A L)$
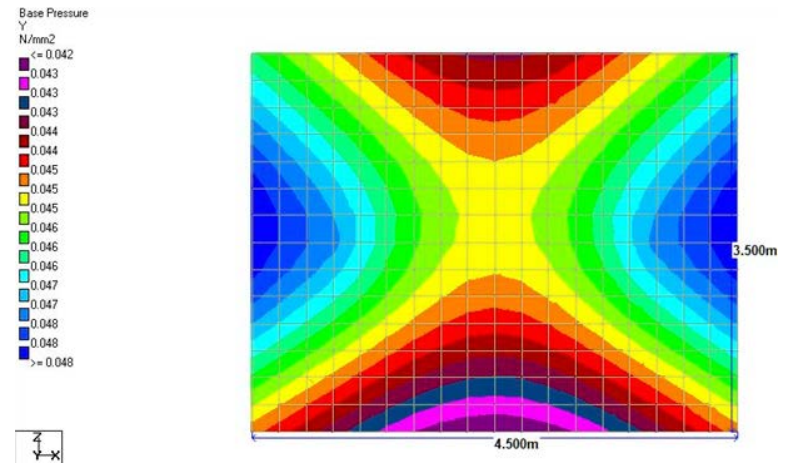

Figure 14 Base pressure distribution in $20 \mathrm{~m}$ truss arrangement $(D L+L L+A L)$
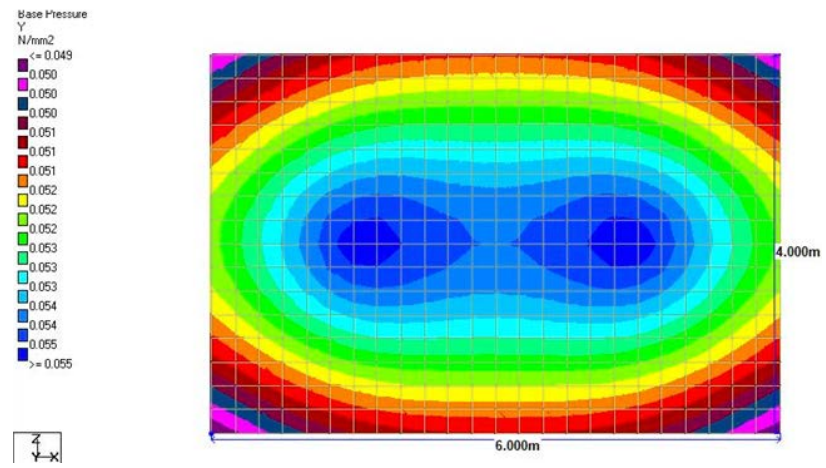

Figure 15 Base Pressure distribution in 30m Girder Arrangement $(D L+L L+A L)$

in cost around 13587.62 USD.

- There is a reduction in settlement characteristics for the truss with an increase in span length from $7.862 \mathrm{~mm}$ to $6.701 \mathrm{~mm}$; whereas for the girder arrangement, the settlement characteristics increase from $7.577 \mathrm{~mm}$ to $9.151 \mathrm{~mm}$.

The conclusion differs for spans less than and more than $15 \mathrm{~m}$ lengths. For a comparatively shorter span length i.e., less than $15 \mathrm{~m}$, the girder with a hanger arrangement is efficient; but for a span length of more than $15 \mathrm{~m}$, the truss

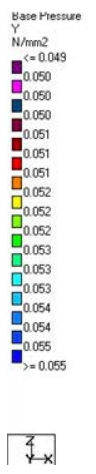

is more efficient.

\section{Declaration and competing interest}

We declare that we have no significant competing interests, including financial or non-financial, professional, or personal interests interfering with the full and objective presentation of the work described in this manuscript.

\section{Acknowledgments}

The authors thank Sri Sivasubramaniya Nadar College of Engineering College, Chennai, India - Management for their support to use the computer labs to do the analysis.

\section{Funding}

The author(s) received no financial support for the research, authorship, and/or publication of this article.

\section{Authors contribution}

Dr. Sivapriya S.V analysed the result and complied the paper. Where S. Sadhana, N. Prathibha and S. Saranya did the analysis for this study.

\section{Data availability statement}

The authors confirm that the data supporting the findings of this study are available within the article [and/or] its supplementary materials. 


\section{References}

[1] R. M. Drake and R. J. Walter, "Design of structural steel pipe racks," Engineering Journal, 2010. [Online]. Available: https://sefindia.org/ forum/files/design_of_structural_steel_pipe_racks_115.pdf

[2] Steel Piperack Design, Onshore Structures standards Committee, 2002. [Online]. Available: https://www.sefindia.org/forum/files/ design_of_piperack_133.pdf

[3] N. J. Singh and M. Ishtiyaque, "Optimized design and analysis of steel pipe racks for oil and gas industries as per international codes and standards," IJRET: International Journal of Research in Engineering and Technology, vol. 5, no. 10, Oct. 2016. [Online]. Available: t.ly/2jzID

[4] 0. Bedair, "Rational design of pipe racks used for oil sands and petrochemical facilities," Practice Periodical on Structural Design and Construction, vol. 20, no. 2, May. 2015. [Online]. Available: https://doi.org/10.1061/(ASCE)SC.1943-5576.0000224

[5] S. López-Chavarría, A. Luévanos-Rojas, and M. Medina-Elizondo, "Optimal dimensioning for the corner combined footings," Advances in Computational Design, vol. 2, no. 2, 2017. [Online]. Available: https://doi.org/10.12989/acd.2017.2.2.169

[6] EMETL, EMETL Practice standards, 2018

[7] Process Industry Practices Machinery PIP REEE005, Construction Industry Institute, 2007.

[8] Code of Practice for Design Loads (Other than Earthquake) for Buildings and Structures, Part 3: Wind Loads, Bureau of Indian Standards, 1987.

[9] Technical refence manual, Bentley Sustaining Infrastructure, 2012.

[10] Foundation Design Solutions, ImageGrafix Engineering Services Pvt.Ltd, 2020. 